\title{
Effect of defaunation on the metabolism of rumen micro-organisms
}

\author{
BY D. I. DEMEYER AND C. J. VAN NEVEL \\ Laboratorium voor Voeding en Hygiene, Rijksuniversiteit Gent Proefhoevestraat, Io, \\ B-9230 Melle, Belgium
}

(Received 7 March 1979 - Accepted 17 May 1979)

I. Rumen contents of a fasted fistulated wether, obtained in a faunated, defaunated and refaunated period were incubated in vitro with a mixture of cellobiose and maltose, in the presence of ammonium bicarbonate and ${ }^{32} \mathrm{PO}_{4}{ }^{3-}$. Total synthesis of microbial $\mathrm{N}\left(\mathrm{N}_{t}\right)$ was calculated from ${ }^{32} \mathrm{P}$ incorporation and $N: P$ determined in microbial matter. The $N: P$ value was not affected by defaunation. Net synthesis of microbial $\mathbf{N}\left(\mathbf{N}_{n}\right)$ was calculated from ammonia- $\mathbf{N}$ incorporation. An estimate of degradation of microbial $\mathrm{N}$ was calculated as $\mathrm{N}_{t}-\mathbf{N}_{n}$. Energetic efficiency of synthesis was calculated from the volatile fatty acids produced during incubation, as $\mathrm{g} \mathrm{N}$ incorporated per $\mathrm{kg}$ organic matter fermented $(\mathrm{g} \mathrm{N} / \mathrm{kg} \mathrm{OM})$.

2. Defaunation decreased the proportions of acetate, butyrate and methane and increased those of propionate in fermentation end-products. Fermentation rate when expressed per $\mathrm{mg}$ microbial $\mathrm{N}$ was not affected by defaunation.

3. Expressed per unit volume of rumen contents, $\mathrm{N}_{n}$ was increased by defaunation whereas $\mathrm{N}_{t}$ remained unchanged. Thus, a decrease in degradation can be calculated. Energetic efficiences of total and net synthesis were increased from 35 and 13 to 47 and $30 \mathrm{~g} \mathrm{~N} / \mathrm{kg} \mathrm{OM}$ respectively.

4. Specific rates of both total and net synthesis of microbial $N$ were significantly increased by defaunation whereas the specific rate of degradation was not affected.

In preliminary experiments designed to study the effect of methane inhibitors on rumen microbial growth, the addition of linseed oil hydrolysate to incubations with rumen contents often resulted in higher efficiences of total synthesis of microbial N (Demeyer \& Van Nevel, I 975 a). Microscopic examination revealed that the protozoa present in such incubations were disintegrated during incubation, and numerous cell fragments could be observed. This suggested that elimination of protozoa from the rumen ecosystem might result in an increased efficiency of microbial growth, which is in agreement with results of in vivo experiments reported by Lindsay \& Hogan (1972). It is indeed well known that in the rumen, protozoa engulf and digest bacteria (Coleman, 1975), resulting in considerable nitrogen recycling within the rumen (Nolan et al. 1972). However, the same phenomenon caused several authors to argue that the presence of protozoa increases bacterial growth efficiency: bacterial numbers are reduced, but the remaining fractions have higher specific growth rates and hence higher growth efficiencies (Kurihara et al. 1968; Thomas, 1973; Prins \& van den Vorstenbosch, 1975; Jouany \& Senaud, 1978). It is obvious that these apparently opposing effects of protozoa are related to different definitions of bacterial growth. The former effect involving lysis of bacteria will decrease net growth of bacteria, whereas the latter effect involving an increase in specific growth rate of bacteria may result in higher efficiencies of total growth of bacteria (not corrected for lysis). In order to differentiate between these phenomena we investigated the effect of defaunation of the rumen of a sheep on synthesis and degradation of microbial $\mathbf{N}$. Both factors were measured in vitro using methods detailed previously (Van Nevel \& Demeyer, 1977).

\section{MATERIALS AND METHODS}

Experimental animal and defaunation

A wether (approximately $75 \mathrm{~kg}$ ) with permanent rumen fistula was penned separately from the other animals. Food (400 g commercial concentrates, $200 \mathrm{~g}$ hay) was kept in the same room for at least $3 \mathrm{~d}$ before feeding (twice daily at 10.00 and 16.00 hours). The animal was 
defaunated following one of the procedures described by Orpin (1977): on two consecutive days, Io g mannoxol O.T (dioctylsodium sulphosuccinate, BDH chemicals, Poole, Dorset) was introduced through the fistula. Food was withheld on the first day and only hay was fed on the second day. For refaunation, I00 $\mathrm{ml}$ rumen contents of a faunated sheep, was introduced through the fistula.

The experiment consisted of three periods, during which rumen contents were sampled for analysis and incubation. A first control period (period I, 4 weeks) was followed by a defaunation period (period 2, 4 weeks) and a second control period after refaunation (period 3, 7 weeks). Samples of rumen contents were obtained for analysis and incubation after an adaptation period of 1 week (periods 1 and 2) or 3 weeks (period 3).

\section{Incubations}

Rumen contents were sampled and incubated with $\mathrm{H}_{3}{ }^{32} \mathrm{PO}_{4}$ as described earlier (Van Nevel \& Demeyer, 1977). For incubation, contents were sampled after a fasting period of $24-48 \mathrm{~h}$ and strained through two layers of surgical gauze. Cellobiose and maltose $(250 \mu \mathrm{mol}$ of each) were used as substrate with $10 \mathrm{mg} \mathrm{N}$ as ammonium bicarbonate and the incubation period was $2 \mathrm{~h}$. Samples of rumen contents, for analysis of volatile fatty acids (VFA) and determination of $\mathrm{pH}$ were obtained $3.5 \mathrm{~h}$ after feeding. During period 3 (week 5 ) the animal refused food for a few days. Incubations carried out during the week after food refusal showed excessive production of lactate and these values were discarded.

\section{Preparation of microbial matter for determination of $N: P$}

On several occasions, subsamples of strained rumen contents $(25 \mathrm{ml})$ were taken before incubation and kept at $-18^{\circ}$ for up to 3 weeks. After thawing the contents were acidified with $0.5 \mathrm{ml} 5 \mathrm{M}$-sulphuric acid, centrifuged ( $25000 \mathrm{~g}$ for $\mathrm{I} 5 \mathrm{~min}$ at $2^{\circ}$ ) and the precipitate washed twice with sodium chloride $\left(9^{\circ} \circ \mathrm{g} / \mathrm{l}\right)$. The pellet, assumed to consist predominantly of microbial matter, associated with some crude fibre, was rehomogenized in water and the homogenate used for $\mathrm{N}$ (micro-Kjeldahl) and $\mathrm{P}$ (after digestion with perchloric acid $700 \mathrm{~g} / \mathrm{l})$ determination.

Some samples were not acidified and it was found that in such samples more $P$ was precipitated, possibly because of precipitation of acid-soluble phosphates of non-microbial origin. The $\mathrm{N}: \mathrm{P}$ value (mean $( \pm \mathrm{SE}$ ) value for twelve determinations) thus obtained was found to be $73.2 \pm 3.3 \%$ of the value obtained after acidification and this factor was used to correct the results for non-acidified samples. On some occasions washed cell suspensions of rumen bacteria (WCS) were prepared as described by Demeyer \& Henderickx (1967) but using Hungate's (1969) solutions A and B instead of phosphate buffer and centrifuging for $10 \mathrm{~min}$ at $22000 \mathrm{~g}\left(2^{\circ}\right)$ instead of $30 \mathrm{~min}$ at $5000 \mathrm{~g}$. WCS were prepared from rumen contents obtained $3.5 \mathrm{~h}$ after feeding. The precipitate obtained after two washings with $\mathrm{NaCl}(9 \mathrm{~g} / \mathrm{l})$ was used for $\mathrm{P}$ and $\mathrm{N}$ determination.

\section{Microbial counts}

Rumen samples (approximately $20 \mathrm{ml}$ ) for counting protozoa and bacteria (total viable anaerobic count) were taken usually three times per week at 13.30 hours. A portion $(0.2 \mathrm{ml})$ was inoculated and diluted in duplicate in roll tubes, essentially as outlined by Hungate ( I 969).

The culture medium ( $4 \mathrm{ml} /$ tube) was the RGCSA medium of Grubb \& Dehority (1976) and the incubation gas was carbon dioxide. Colonies were counted at least $4 \mathrm{~d}$ after inoculation. Protozoa were counted as described by Prins (1967), but a Hawskley counting chamber was used (Hawskley, England). 
Analyses

Methane and hydrogen in the gas phase and VFA, lactic acid, inorganic $\mathrm{P}$ as phosphate, ammonia-N (AN), and soluble total $N$ (STN) in the supernatant fraction of the acidified and centrifuged $\left(25000 \mathrm{~g}, \mathrm{I} 5 \mathrm{~min}\right.$ at $\left.2^{\circ}\right)$ incubation mixture were determined as described previously, as well as total $\mathrm{N}(\mathrm{TN}$; microbial $\mathrm{N})$ and radioactivity in the washed pellet (Van Nevel \& Demeyer, 1977). Total sugars were determined on a portion of the whole incubation mixture using the phenol- $\mathrm{H}_{2} \mathrm{SO}_{4}$ method (Herbert et al. $197 \mathrm{I}$ ).

\section{Calculations}

Total synthesis of microbial $\mathrm{N}$ was estimated from the total incorporation of $\mathrm{P}\left(\mathrm{P}_{t}\right)$ calculated from the radioactivity incorporated in the centrifuged and washed microbial matter and the specific activity of the phosphate pool, as described previously (Van Nevel \& Demeyer, 1977).

Total incorporation of $\mathrm{N}\left(\mathrm{N}_{t}\right)$ was calculated from $\mathrm{P}_{t}$ using the $\mathrm{N}: \mathrm{P}$ value determined in microbial matter. Net synthesis of microbial $\mathrm{N}$ was estimated from the net incorporation of $\mathrm{N}\left(\mathrm{N}_{n}\right)$ equivalent to the net disappearance of $\mathrm{AN}$ or STN in the supernatant fraction obtained after centrifugation or both. An estimate of degradation of microbial $\mathbf{N}$ was obtained from the difference $\mathrm{N}_{t}-\mathrm{N}_{n}$, being the amount of microbial $\mathrm{N}$ degraded to STN or AN during incubation. The concepts of total and net synthesis of microbial matter were discussed earlier (Van Nevel \& Demeyer, 1977).

Efficiencies of total and net synthesis of microbial $\mathrm{N}$ were expressed as $\mathrm{g} \mathrm{N} / \mathrm{kg}$ organic matter fermented $\left(O M_{f}\right)$ where $O M_{f}$ was calculated from the theoretical amount of hexose fermented $\left(\mathrm{C}_{6} \mathrm{f}\right)$ using $\mathrm{I} 62$ as molecular weight of a hexose monomer in organic matter. The latter was calculated from the VFA produced (corrected for the initial amounts present) during incubation as $\mathrm{C}_{6} \mathrm{f}=\frac{1}{2} A+\frac{1}{2} P+B+V+\frac{1}{2} L$ where $A$ is acetate, $P$ is propionate, $B$ is butyrate, $V$ is valerate and $L$ is lactate produced.

The accuracy and validity of analytical values obtained from incubations was tested by calculation of $2 \mathrm{H}$ recoveries. Such calculations involving stoichiometry have been described earlier (Marty \& Demeyer, I973; Demeyer \& Van Nevel, 1975a).

\section{Statistics}

Results were subjected to a single factor analysis of variance, where mean values obtained in period 2 were compared to the over-all means of periods I and 3 using the $F$ test for significance (Campbell, 1967).

\section{RESULTS \\ Microbial counts}

Protozoal counts and numbers of total viable anaerobic bacteria are shown in Table I. It is clear that defaunation completely and persistently removed protozoa, whereas the total number of viable anaerobic bacteria was more than doubled. Although differences were not significant, the results do suggest that refaunation did not completely restore the concentrations of protozoa and bacteria to original values.

\section{Composition of rumen contents and fermentation pattern}

Table 2 shows that defaunation resulted in a significant increase in the molar proportion of propionate in the the VFA whereas the butyrate fraction was significantly decreased. The effect on propionate however was only observed $3.5 \mathrm{~h}$ after feeding and the effect on butyrate only after a fasting period of $24-48 \mathrm{~h}$.

Rumen samples obtained after such fasting periods were used in incubations and were 
Table I. Effect of defaunation on total protozoa and total viable count of anaerobic bacteria $($ cells $/ m l)$

(Mean values with their standard errors, no. of determinations in parentheses)

$\begin{array}{ccc}\text { Period } & \text { Protozoa }\left(\times 10^{6}\right) & \text { Bacteria }\left(\times 10^{10}\right) \\ \text { I } & 2.31^{\mathrm{a}} \pm 0.24 & 0.81^{\mathrm{a}} \pm 0.09 \\ & (9) & (8) \\ 2 & 0 & 4.32^{\mathrm{b}} \pm 0.41 \\ & (19) & (19) \\ 3 & 0.54^{\mathrm{a}} \pm 0.59 & 1 \cdot 27^{\mathrm{a}} \pm 0.23 \\ & (18) & (15)\end{array}$

$a, b$, Values in the same column with different superscripts were significantly different $(P<0 \cdot 01)$ by the $t$ test (Snedecor, 1955).

essentially devoid of endogenous substrates as evidenced by the low total VFA concentration. Defaunation decreased concentration of $A N$ and microbial $\mathrm{N}$ in such samples on the border of significance, but the importance of these results is limited as concentrations of all components measured were very low and are only presented for completeness. Much more significant effects can be deduced from values obtained in vitro (Table 3).

Defaunation shifts the fermentation pattern to increased propionate production, associated with lower acetate, butyrate and methane production. The total amount of theoretical hexose fermented is lowered by defaunation. This effect is probably due to a lower microbial $\mathrm{N}$ content of the samples as no significant difference is observed when fermentation activity is expressed as $\mu \mathrm{mol} \mathrm{C}_{6}$ per $\mathrm{mg}$ microbial $\mathrm{N}$ initially present in the incubations (Table 3 ).

\section{$N: P$ in microbial matter}

Table 4 shows that defaunation did not change the $N: P$ value in mixed microbial matter obtained from rumen samples after $24-48 \mathrm{~h}$ fasting. However, the value obtained is considerably lower than the mean value obtained in previous work $(8 \cdot 37 \pm 0 \cdot 75)$ using different sheep given different diets over a period of 2 years (Van Nevel \& Demeyer, 1977).

Values obtained using WCS of rumen bacteria (Table 3) were also lower than the mean value obtained previously $(6 \cdot 05 \pm 0 \cdot 80)$. Samples of rumen contents were filtered through surgical gauze in the present work, whereas in previous work a metal gauze was used; however, the use of gauze was found to increase the N:P value only slightly if at all. Although it is known that the chemical composition of rumen microbes may vary with animal, diet and environment (Smith \& McAllan, 1974), the precise reasons for the low values obtained in this experiment are unknown. In further calculation of $\mathrm{N}_{t}$ an over-all mean value for $\mathrm{N}: \mathrm{P}$ of $4.43 \pm 0.22$ (mean ( $\pm \mathrm{SE}$ ) for the thirteen determinations of Table 3 ) was used.

\section{Synthesis and degradation of microbial $N$}

Table 5 shows estimates for total synthesis $\left(\mathrm{N}_{t}\right)$ as well as for net synthesis $\left(\mathrm{N}_{n}\right)$ as $\mu \mathrm{g} N$ incorporated into microbial matter during incubation.

For net synthesis, values for net AN incorporation only were used as it was found for all incubations that STN incorporation was $94 \pm 7 \%$ AN incorporation (mean ( \pm SE) for eighteen incubations). Values for net synthesis were significantly increased by defaunation. When synthesis ( $\mathrm{N}$ incorporation) was related to the initial microbial $\mathrm{N}$ content of the incubation (specific rate of synthesis) a significant increase of both total and net specific synthesis can be observed after defaunation. Calculated rate of degradation $\left(\mathrm{N}_{t}-\mathrm{N}_{n}\right)$ was significantly lowered by defaunation when expressed per unit volume of rumen contents, 


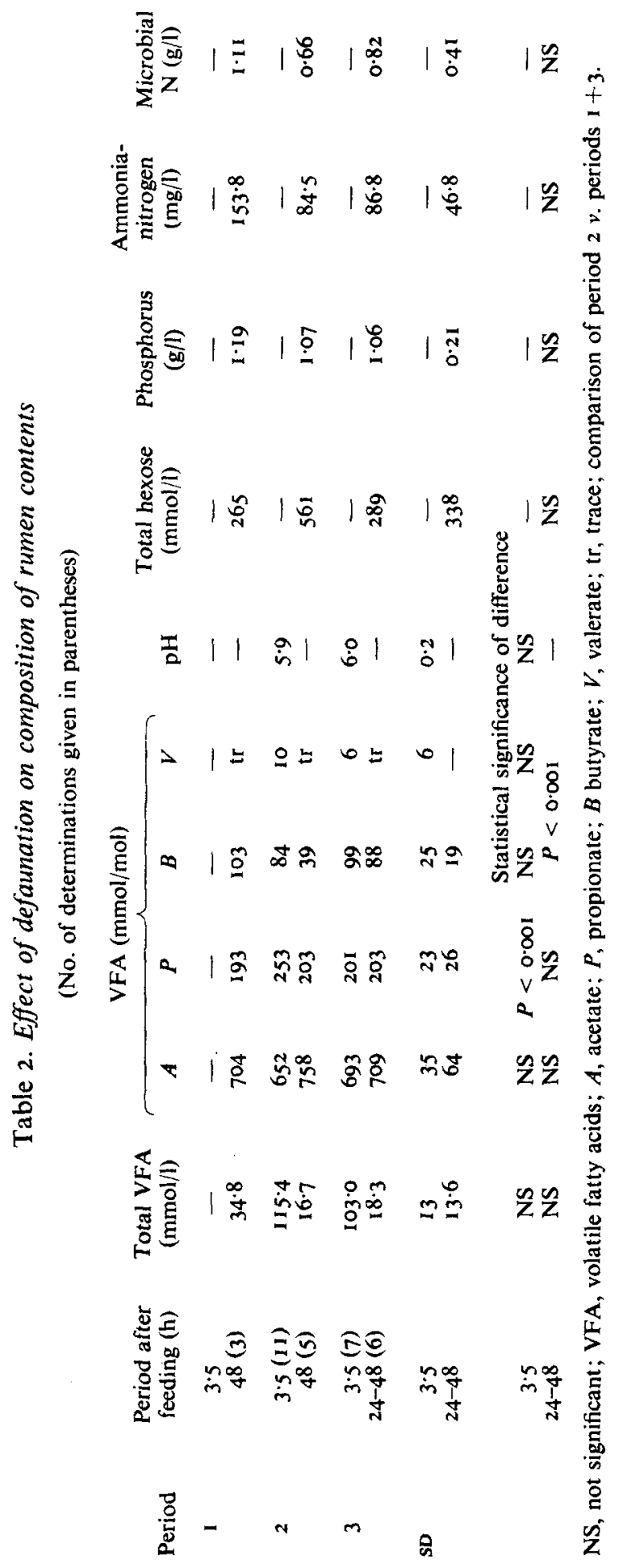




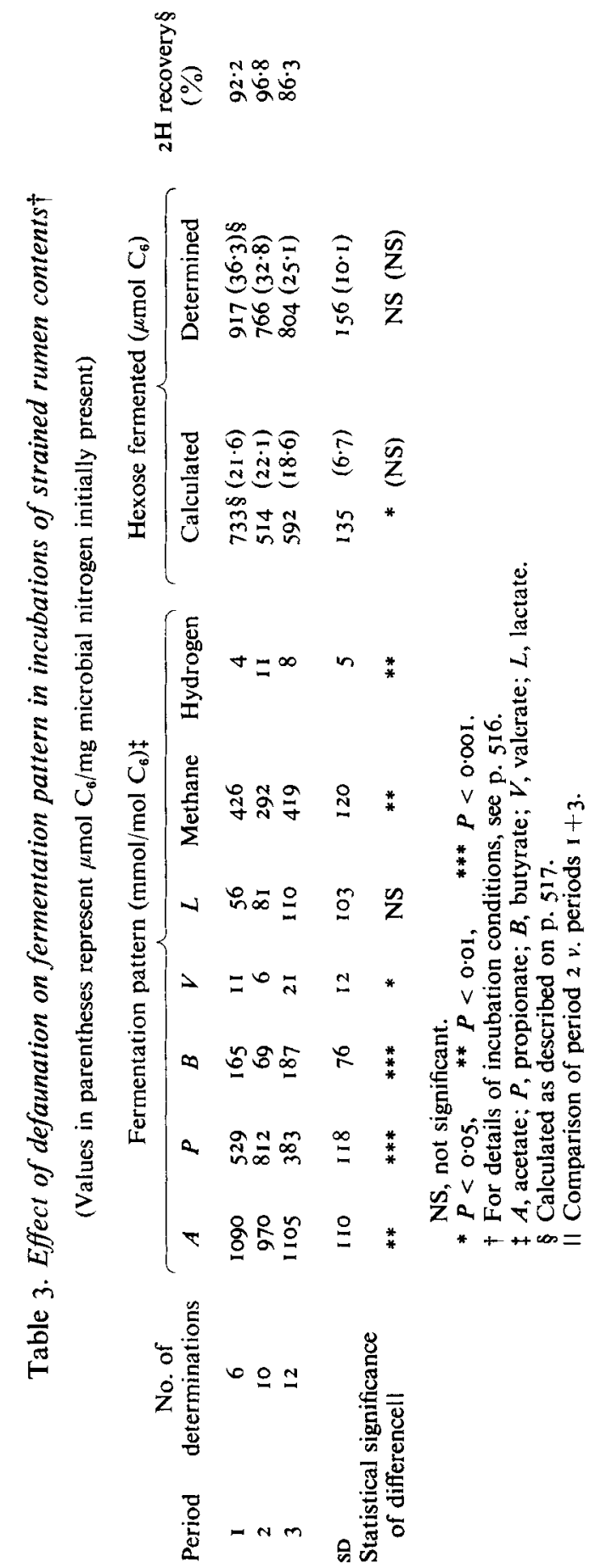


Table 4. Value for nitrogen:phosphorus in rumen microbial matter

(No. of determinations given in parentheses)

\begin{tabular}{lcc} 
Period & $\begin{array}{c}\text { Washed cell } \\
\text { suspensions* }\end{array}$ & $\begin{array}{c}\text { Mixed } \\
\text { microbial matter* }\end{array}$ \\
\multicolumn{1}{l}{ I } & $4.96(2)$ & - \\
2 & $4.48(12)$ & $4.26(7)$ \\
3 & $4.57(19)$ & $4.63(6)$ \\
SD & 0.66 & 0.44 \\
Over-all & & $4.43 \pm 0.22$ \\
mean \pm SE & & * For details, see p. 516.
\end{tabular}

but remained the same in all three periods when expressed per $\mathrm{mg}$ microbial $\mathrm{N}$ present in the incubations (specific rate of degradation).

Efficiencies of synthesis when related to $\mathrm{OM}_{\mathrm{f}}$ were significantly higher in the defaunated state for both total and net synthesis.

\section{DISCUSSION}

The changes observed after defaunation agree with earlier observations of microbial counts (Bryant \& Small, I960; Eadie \& Hobson, I962; Eadie \& Gill, 197I; Orpin, 1977) and fermentation pattern (Abou Akkada \& El-Shazly, 1964; Christiansen et al. 1965; Kurihara et al. 1968; Males \& Purser, 1970). The increase in the total viable anaerobic count of bacteria is obviously related to the elimination of predation of bacteria by protozoa (Hungate, I972). It should be clear, however, that a higher viable count is not necessarily paralleled by an increase in bacterial numbers in the rumen. Indeed an increased count may reflect increased viability because of a higher specific growth rate as viability and specific growth rate are positively related, especially at the low dilution rates normally present in the rumen (Tempest et al. 1967). Although bacterial counts were increased by defaunation, the microbial $\mathrm{N}$ concentration in the rumen tended to be lowered as the period after feeding increased (Table 1). This suggested that the increase in bacterial $\mathrm{N}$ brought about by defaunation was not sufficient to replace the protozoal $N$ loss in the total amount of microbial $\mathrm{N}$. Both in vitro and in vivo VFA compositions were shifted towards higher propionate and lower butyrate proportions. The decrease in butyrate production observed in vitro illustrates the important role of protozoa in this process (Youssef \& Allen, 1968) and indicated important protozoal metabolic activity in our incubations. The decrease in the butyrate fraction of the VFA in vivo was only observed at a long period after feeding, whereas the increase in the propionate fraction is not apparent at that time. These findings may be related to the maximum levels of protozoa observed at a long period after feeding (Michailowski \& Musżynski, 1978) and the predominant fermentation activity of bacteria forming propionate, shortly after feeding (Hungate, I966).

It should be mentioned that on a molasses diet, defaunation was shown to result in an increased butyrate proportion in rumen VFA (Bird \& Leng, 1978). The high butyrate proportions observed on molasses diets, however, are probably of bacterial origin (Elias, I 972). In line with stoichiometry, the observed changes in propionate and butyrate productions are accompanied by a decreased methane and acetate production in vitro (Demeyer \& Van Nevel, 1975a). These changes may be related to the absence of propionate production in protozoa, which normally release $\mathrm{H}_{2}$ and formate, both products being precursors for methane production (Hungate, 1966). Interpretation of results related to synthesis and degradation of microbial $\mathrm{N}$ is difficult. When expressed per $100 \mathrm{ml}$ of rumen fluid, it is clear 


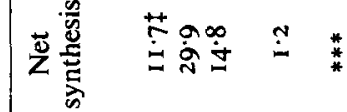


that net synthesis of $\mathrm{N}\left(\mathrm{N}_{n}\right)$ is significantly increased by defaunation, whereas no difference is observed in total synthesis of $\mathrm{N}\left(\mathrm{N}_{t}\right)$ (Table 5). Therefore calculated degradation $\left(\mathrm{N}_{t}-\mathrm{N}_{n}\right)$ is significantly lowered by defaunation. It is tempting to conclude that the observed increase in net synthesis is related to the calculated decrease in degradation, the latter being the result of the removal of protozoa. Indeed, protozoa are predators of bacteria with release of non protein $\mathrm{N}$ in the medium (Coleman, 1975 ) and are thought to be the main factor responsible for degradation and recycling of bacterial $\mathrm{N}$ within the rumen (Jarvis, 1968). The argument receives further support when results for growth efficiencies are considered: efficiency of net synthesis is approximately doubled by defaunation, in line with recent in vivo work (Knight et al. 1978). However, the efficiency of total synthesis is also increased significantly. The latter finding is more difficult to explain and may be related to reduced synthesis of polysaccharide in the absence of protozoa, more energy being used in $\mathrm{P}$ and $\mathrm{N}$ incorporation (Van Nevel \& Demeyer, 1977). According to Thompson \& Hobson (1971), however, bacteria may be more important than protozoa in polysaccharide synthesis. Differences in $\mathrm{N}$ : $\mathrm{P}$ of the growing micro-organisms in periods $\mathrm{I}$ and 3 as compared to period 2 may also be involved. It is likely that differences in the composition of the microbial matter synthesized in faunated and defaunated rumen contents are responsible for the observed increase in efficiency of total synthesis. Indeed, defaunation produced no increase in fermentation rate (Table 3 ), indicating that the proportion of energy used for microbial maintenance was not decreased. Also, the changes in fermentation pattern brought about by defaunation are not likely to affect efficiency (Demeyer \& Van Nevel, 1975b). However, it cannot be discounted that bacteria grow more efficiently in the absence of protozoa than when there is a mixed microbial population. In a mixed population the bacterial specific growth rate may well be increased by predation, but this effect may not be reflected in an increased growth efficiency of the total population because of the longer generation times and higher maintenance requirement of protozoa being more important in determining growth efficiency of the mixed population.

The increase observed after defaunation in absolute values of net synthesis as well as in values of efficiency of net synthesis may be explained in terms of decreased degradation of bacteria. The latter, however, is not apparent when both synthesis and degradation are expressed per unit of $\mathrm{N}$ present in the incubation (specific rates of synthesis and degradation). Table 5 shows that specific rates of both total and net synthesis are increased by defaunation, whereas the specific rate of degradation remains unaltered at a value of approximately $0.03 / \mathrm{h}$. This finding could mean that the absence of protozoa does not change the proportion of microbial $\mathrm{N}$ recycling within the rumen but increases growth efficiency of the microbial population by omission of an energetically inefficient step in the over-all synthesis of microbial matter. This conclusion contrasts with the general belief that engulfment of bacteria by protozoa is the process mainly responsible for release of bacterial non-protein- $N$ in the rumen reflected in higher rumen ammonia levels in faunated than in defaunated animals (Coleman, I975). However, there is no direct evidence for this theory and it has been shown that other factors in addition to protozoa may be important in degradation of rumen bacteria (Paynter et al. 1969; Jarvis, 1968; Hoogenraad \& Hird, I970; Robinson \& Hungate, 1973). Assuming an engulfment rate of 50 bacteria/protozoon per min. (Coleman, 1975) with $50 \%$ of the bacterial $N$ engulfed being liberated as ammonia, it can be calculated that such rate only accounts for approximately $40 \%$ of the values for degradation presented in Table 5. However, it should be stressed that the values for degradation of microbial $\mathrm{N}$ presented are calculated assuming that the $\mathrm{N}: \mathrm{P}$ value in newly formed microbial matter is not affected by defaunation. This assumption needs further investigation before it can be concluded beyond doubt that defaunation does affect the specific rate of total synthesis of microbial $\mathrm{N}$, rather than the specific rate of degradation. 
The authors acknowledge the help of C. Vermander, G. De Decker, M. Faquaet and Annie Lejeune in the analytical work and preparation of the manuscript. The research is sponsored by the IWONL, Brussels, Belgium.

\section{REFERENCES}

Abou Akkada, A. R. \& El-Shazly, K. (1964). Appl. Microbiol. 12, 384.

Bird, S. H. \& Leng, R. A. (1978). Br. J. Nutr. 40, I63.

Bryant, M. P. \& Small, N. (1960). J. Dairy Sci. 43, 654.

Campbell, R. C. (1967). Statistics for Biologists, p. I34. London: Cambridge University Press.

Christiansen, W. C., Kawashima, R. \& Burroughs, W. (I965). J. Anim. Sci. 24, 730.

Coleman, G. S. (1975). In Digestion and Metabolism in the Ruminant, p. 149 [I. W. McDonald and A. C. I.

Warner, editors]. Armidale, New South Wales: University of New England Publishing Unit.

Demeyer, D. I. \& Henderickx, H. K. (1967). Biochem. J. 105, 27 I.

Demeyer, D. I. \& Van Nevel, C. J. (1975a). In Digestion and Metabolism in the Ruminant, p. 366 [I. W. McDonald and A. C. I. Warner, editors]. Armidale, New South Wales: University of New England Publishing Unit.

Demeyer, D. I. \& Van Nevel, C. J. (1975b). Misc. Papers, Landbouwhogeschool Wageningen II, 31.

Eadie, J. M. \& Gill, J. C. (I971). Br. J. Nutr. 26, 155.

Eadie, J. M. \& Hobson, P. N. (1962). Nature, Lond. 193, 503.

Elias, A. (1972). PhD Thesis cited by P. Hobson, Proc. Nutr. Soc. 31, 135.

Grubb, J. A. \& Dehority, B. A. (I976). Appl. Env. Microbiol. 31, 262.

Herbert, D., Phipps, P. J. \& Strange, R. E. (197I). Meth. Microbiol. 5 B, 209.

Hoogenraad, N. J. \& Hird, F. J. R. (I970). J. gen. Microbiol. 62, 26I.

Hungate, R. E. (1966). The Rumen and its Microbes, p. I37. London and New York: Academic Press.

Hungate, R. E. (1969). Meth. Microbiol. 3 B, 117.

Hungate, R. E. (I972). Am. J. clin. Nutr. 25, 1480.

Jarvis, B. D. W. (Ig68). Appl. Microbiol. 16, 714.

Jouany, J. P. \& Senaud, J. (1978). Annls Zoötech. $27,61$.

Knight, R., Sutton, J. D., McAllan, A. B. \& Smith, R. H. (1978). Proc. Nutr. Soc. 37, 14 A.

Kurihara, Y., Eadie, J. M., Hobson, P. N. \& Mann, S. O. (I968). J. gen. Microbiol. 51, 267.

Lindsay, J. R. \& Hogan, J. P. (1972). Aust. J. agric. Res. 23, 32 I.

Males, J. R. \& Purser, D. B. (1970). Appl. Microbiol. r9, 485.

Marty, R. J. \& Demeyer, D. I. (1973). Br. J. Nutr. 30, 369.

Michailowski, T. \& Musżynski, P. (I978). J. agric. Sci., Camb. 9o, 1.

Nolan, J. V., Norton, W. B. \& Leng, R. A. (1972). Tracer Studies on Non-protein Nitrogen for Ruminants, p. 13. Vienna: International Atomic Energy Agency.

Orpin. C. G. (1977). J. appl. Bact. 43, 309.

Paynter, M. J. B., Ewert, D. L. \& Chalupa, W. (1969). Appl. Microbiol. 18, 942.

Prins, R. A. (1967). Enkele microbiologische en biochemische aspecten van de stofwisseling in de pens. PhD Thesis, State University Utrecht, The Netherlands.

Prins, R. A. \& van den Vorstenbosch, C. J. A. H. V. (I975). Misc. Papers Landbouwhogeschool Wageningen II, I5.

Robinson, J. P. \& Hungate, R. E. (1973). Int. J. Syst. Bact. 23, 171.

Smith, R. H. \& McAllan, A. B. (1974). Br. J. Nutr. 31, 27.

Snedecor, G. W. (1955). Statistical Methods, p. 75. Ames, Iowa: lowa State College Press.

Tempest, D. W., Herbert, D. \& Phipps, P. J. (1967). In Microbial Physiology and Continuous Culture, p. 240 [E. O. Powell, C. G. T. Evans, R. E. Strange and D. W. Tempest, editors]. London: H.M. Stationery Office.

Thomas, P. C. (1973). Proc. Nutr. Soc. 32, 85.

Thompson, J. K. \& Hobson, P. N. (1971). J. agric. Sci., Camb. 76, 423.

Van Nevel, C. J. \& Demeyer, D. I. (I977). Br. J. Nutr. 38, IoI.

Youssef, F. G. \& Allen, D. M. (1968). Nature, Lond. 217, 777. 